\title{
Identity, Place and Non-belonging in Jean Rhys's Fiction
}

\author{
Lin Yan \\ Shanghai International Studies University, Shanghai, China
}

\begin{abstract}
Place is considered as a distinguishable factor among Jean Rhys's novels, most concretely represented by three countries: Dominica, England and France. In locating her outsider and outcast heroines in these places of interconnectedness, Rhys's fiction responds to a time of crisis in the history of Empire. With a much stigmatized white West Indian creole identity, her heroines are unacceptably white in Dominica, and unacceptably "black" in Europe. In Voyage in the Dark, Anna is stranded in a modernist London that was at once racially heterogeneous, cosmopolitan and xenophobic. Her transgressive and mobile identities (racial, sexual, national), are forever making her stranger in the metropole. In Quartet and Good Morning, Midnight, both Marya and Sasha occupy the temporary and liminal spaces of the metropolis of Paris and try to buy themselves an illusion of a respectable identity. Rejected, unhoused, wandering in a state of limbo, their existence becomes mechanical and ghostly. It is this sense of having no identity and no place of belonging resulted from a very specific and traumatic colonial experience that best explains the pervasive tone of loss, melancholy, and paralysis of spirit underlying all of Rhys's fiction.
\end{abstract}

Index Terms - Jean Rhys, identity, place, non-belonging, modernism

\section{INTRODUCTION}

Amidst the increasing volumes of Rhys studies, there remained for a long time a schism between her European/metropolitan fiction and her fiction with more obvious West Indian background. As she became "a central literary icon"(Savory, 2009, p.xiv) with the rise of feminist and postcolonial studies and receives increasing attention as a Caribbean or West Indian writer, a large number of these studies framed the discussion within the rich and diverse tradition of Caribbean literature and culture as the essential context of Rhys's Caribbean texts, most notably Wide Sargasso Sea and a number of short stories, whereas the early novels, with their metropolitan settings and protagonists of overt English background, continue to be approached from (European) modernist and feminist perspective. Only until recently has critics begun to merge the two strains of writing, bringing together various camps of modernist, feminist Caribbean and postcolonial studies.

Unlike the other expatriate writers of the thirties in London and Paris, Rhys was not simply the metropolitan outsider who experienced a modernist alienation and exile. She was the West Indian who made the reverse journey from the colony to the metropole. In this sense, place stands as a distinguishable factor among Jean Rhys's fiction. From a disturbing childhood in a white creole colonizer family in post-slavery Dominica to her later painful entry into the mother country and exile in imperial centers, she struggled with an outsider status, a state she most frankly professes in her biography Smile Please (1979): "I would never belong anywhere, and I knew it, and all my life would be the same, trying to belong and failing.... I am a stranger and I always will be, and after all I didn't really care” (p.124). Similarly, the sense of isolation, of not belonging anywhere, the lack of solidity in background - having no name, no face, no country, no dignity, a desperate financial and emotional dependence on men, present in almost all of the Rhys heroines, must be understood in the context of the writer's unique colonial consciousness and as a result of perpetual displacement. And these features may best be illustrated from the interplay of place and identity in Rhys's three early novels: Quartet (1929), Voyage in the Dark (1934) and Good Morning, Midnight (1939).

\section{From DominicA to England: The White Creole Woman’s Limbo}

The story of Voyage in the Dark follows Anna Morgan, a white West Indian teenage girl who is sent to England to study. As a chorus girl, she has an affair with a much older, well-to-do Englishman, Walter Jeffries, who eventually ends the relationship and cut Anna off with money. And she begins a slow slide into prostitution. The novel was originally called "Two Tunes", signifying two quite separate and confrontational worlds of the Caribbean, Anna's childhood home, and England.

Her home island, Dominica, though unnamed in the story, appears in a dreamy vision Anna recalls reading from a travel book:

'Lying between $15^{\circ} 10^{\prime}$ and $15^{\circ} 40^{\prime} \mathrm{N}$. and $61^{\circ} 14^{\prime}$ and $61^{\circ} 30^{\prime} \mathrm{W}$. 'A goodly island and something highland, but all overgrown with woods,' that book said. And all crumpled into hills and mountains as you would crumple a piece of paper in your hand - rounded green hills and sharply-cut mountains." ( Rhys, 1934, p.17) 
The way the island is described obviously mirrors how it had been colonized and treated by the English. Anna recalls the landscape, color, smell of the island with warmth:

"It was funny, but that was I thought about more than anything else - the smell of the streets and the smells of frangipani and lime juice and cinnamon and cloves, and sweets made of ginger and syrup, and incense after funerals or Corpus Christi procession, and the patients standing outside the surgery next door, and the smell of the sea breeze and the different smell of the land-breeze."(Rhys, 1934, p.7)

In contrast, England is "a curious limbo", a cold and thieving place. Here England is obviously a place that is "open, porous and the products of other places" (Massey, 1995, p.59). Anna's shift in temporal, geographical as well as psychic spaces between the colony and metropole brings the history of imperialism to the foreground. The cityscape of London, an imperial metropolis grounded in the material manifestations of wealth and privilege, is fractured by the shadow of imperial history. Its history as a place from and through which the slave trade was controlled, financed and administered is constantly evoked through the heroine's alienated and dreamy experience of the city.

Throughout the novel, Rhys continuously reminds us of the strong foreign presence in modernist London. Contrary to its image of a heterogeneous metropolitan city of racial, sexual and class emancipation the Bloomsbury has successfully established, the foreign characters in VD are constantly conceived of as outsiders, "dirty foreigners" (Rhys, 1934, p.95). Their presence signals simultaneously the heterogeneity and exclusionary nature of modernist London. Rhys also uses characters with ambiguous Jewish identity - the quintessential figure of exile, to conjure physical and emotional displacement.

Anna, the white creole, is the doubly 'not-like', the 'almost the same, but not quite' in two directions, or in Homi Bhabha's phrase, "less than one but double", leaving her in a space of suspension, in between. Back in Dominica, Hester, Anna's stepmother, insinuates that Anna's maternal genealogy-fifth generation West Indian - is tainted by "coloured" blood, and makes redeeming Anna from the "[u]nfortunate propensities" of her maternal family, her mission (Rhys, 1934, p.56). Hester represents a repressive English colonial Law, especially in her maxims concerning the proper behaviour of white ladies and gentlemen. Anna was raised to be a white "lady"; her purity and Englishness was monitored by Hester. But she finds Anna's Dominican accent intolerable and considers Anna as "growing up more like a nigger every day" (Rhys, 1934, p.54). In England the other chorus girls call her "the Hottentot", a term insinuating a pathological sexuality widely held belonging to black women. A hostile landlady sneers at her "drawly voice"(Rhys, 1934, p.18), and she is also called a "fair baboon... worse than a dark one every time" (Rhys, 1934, p.126). Anne McClintock in Imperial Leather discusses the invention of race in the urban metropoles and argues that it became central not only to the self-definition of the middle class but also to the policing of the "dangerous classes" - the working class, the Irish, Jews, prostitutes, feminists, gays and lesbians, criminals (McClintock, 2013, p.5). Anna fits into the category of dangerous class, and the kind of alienation she experiences in England is aptly reflected in an advertisement poster she recalls, in which a little girl and a boy are playing under a tidy green tree and a shiny pale-blue sky with a high dark wall behind the little girl, and "it was the wall that mattered" (Rhys, 1934, p.127).

Anna also experiences a kind of hostility in the metropole manifested in spacial forms. Repeatedly she notes the similarity between the towns, streets, houses, hotel rooms, and landladies, contrasted with her earlier imagination:

"I had read about England ever since I could read - this is London-hundreds thousands of white people rushing along and the dark houses all alike frowning down one after the other, all exactly alike, all stuck together, rotten-looking, the dark streets around the theater made me think of murder." (Rhys, 1934, p.15)

These images indicate the rigidity and inflexibility of a homogenized British culture and the pressure to conform. "Previous lodger, note, horse faces, grey streets where old men wail unnoticed, butcher's shop stinks to the leaden sky, fish shops stinks differently but worse. Loathsome London, vile and stinking hole...." The rooms she finds herself in are invariably cold, small, like as dark box, and she keeps the curtains drown all the time. Windows are "like a trap", "the Iron shroud, all dirt swept under the bed". In one boarding house Anna worries "I believe this damned room's getting smaller and smaller" and imagines that the walls will creep inwards "until they crush her to death"(Rhys, 1934, p.26). As her dwellings space shrinks and presses upon her, she feels her own body becomes unhomely, "three quarters of me was in a prison, wandering round and round in a circle"(Rhys, 1934, p.66). One of her landladies shows her contempt saying that she does not let to professional, as it will give her house a bad name. And she accuses Anna of crawling up the stairs at three in the morning, the stairs being another metaphor for what the high dark wall represents for Anna. When Walter takes Anna to his place, his house also takes on a dark, quiet and watching look, "not friendly" to Anna. It seems to assume the role of the host, "sneering faintly, sneering discreetly, as a servant would", asking Who's this? where on earth did he pick her up?" Even the shop widows sneer at her, stripping her naked, to show herself as an imposter and her attempt to dress like everyone else and buy into the illusion of acceptance, to escape alienation has failed.

Anna, in an ostracized state, suffers from both claustrophobia and agoraphobia. Whether confining herself inside hotel rooms, or subjecting herself to hostile looks and surveillance by policeman on the streets, Anna could find no welcoming place in the metropole. When she moves in with Ethel the masseuse who invites her to share her house and her manicure business, she confines herself within a few rooms and gone from one to another: "You're face to face with a high, dark wall." And the look from the girl at the hotel desk and Vincent are also described in oppressive spacial terms: "The damned way they look at you and their damned voices, like high, smooth, unclimbable walls all around you, 
closing on you." (Rhys, 1934, p.126) And no communication is possible. As Anna wanders in the street, she can't help being in a paranoid state: "I was afraid to cross the street because the slanting houses might fall on me or the pavement rise up and hit me. But most of all I was afraid of the people passing because I was dying, any one of them, any minute, might stop and approach me and knock me down or put their tongues out as far as they would go." As Deborah Parsons has pointed out in Street Waling the Metropolis: "Despite the increased independence and public visibility of women that was gained in the first decades of the twentieth century, the end of the war brought with it a backlash against female emancipation," and "women in public were again associated with the fallen woman.... Their posture of urban knowledge and independence has become futile, sterile, and rather sordid" (Parson, 2000, p.125). Therefore whereas Richardson and Woolf's characters inhabit the space of the urban street and room, manifesting independence and engaging in pilgrimage, those of Rhys choose to inhabit streets and rooms that allow them hiding-places and anonymity. For Anna, "Anywhere will do, so long as it's somewhere that nobody knows"(Rhys, 1934, p.100).

Victor Turner in the Ritural Process proposes the concept of "liminal" condition. For Turner, a liminal condition is ambiguous state that defies normal classifications that may locate a particular body within certain cultural context, and while it represents a transitional state, it may pose danger to others (Rhys, 1934, p.95). As a white Creole, outsider/insider in the metropole, Anna is obviously in an in-between state. Anna feels the hostility from those who perceive her as a danger in an excruciating way that it parallels the violence of slavery as she reflects: "it was terrifying -the way they look at you. So that you know that they would see you burnt alive without even turning their heads away"(Rhys, 1934, p.103). Her experience testifies that "Englishness was itself a product of the colonial culture that it seemed to have created elsewhere" (Gikandi, 1996, p.x). Only by establishing the boundary between self and colonial other can the English identity be constructed. Anna's constant shift of mind between past and present, London and Caribbean, her seeming inability to demarcate the borders of these spaces, temporal, geographical as well as psychic, illustrates on one hand "the disorienting power of modernity" (Thacker, 2003, p. 204), and on the other her resistance to the Empire's insistent mapping of boundaries in all aspects. And her dis-identification with the English opened for her a space from which to gaze critically at the constructedness of Englishness and their gendered and racialized manifestations.

\section{PARIs: The CONSUMing Woman AND THE AUtOMATON}

Rhys left England for the Continent in 1919 and vowed to herself "nothing would ever make me return" (Rhys, 1979, p.172). She spent the most part of the 1920s in Paris and though for some time she did have to leave and return to England, she made frequent visit back to the Continent and her stay seemed particularly fruitful. It was in Paris in 1927, Rhys published her first collection, The Left Bank and Other Stories, and the very next year, her first novel, Quartet (published under the title Postures). It was also mainly in Paris she finished most part of After Leaving Mr. MacKenzie.

Paris, in Rhys's fiction, is Walter Benjamin's capital of modernity, the city of arcades and of department stores. Yet it is not upheld as a place that offered women socially acceptable spaces, the city that fostered the talents of the women artists like Gertrude Stein, Stella Bowen, D'juna Barnes, Gwen John and allowed them to find their own artistic voice. Both Rhys and Benjamin write about Paris and of consumerism that defined urban culture in the early twentieth century, both of their works can be read as cultural analysis of the commodity, the theatre, the dream, fashion and advertising, characters on the margins of society (the prostitute). But for Rhys's heroines, the arcades, the department stores and the flanerie do not represent the promise of consumerism and capitalism that define modern European culture. The racial and imperialist factors behind the commodity capitalism always complicate the picture. MccLintock calls the three of the governing themes of Western imperialism: "the transmission of white, male power through control of colonized women; the emergence of a new global order of cultural knowledge; and the imperial command of commodity capital" (McClintock, 2013, p.3). The imperialist control of women and commodity at the empire center is given particular emphasis in Rhys's European novels.

Good Morning, Midnight illustrates the importance of space in the novel:

"Was it in 1923 or 1924 that we lived round the corner, in the Rue Victor Cousin, and Enno bought me that Cossack cap and the imitation astrakhan coat? It was then that I started calling myself Sasha. I thought it might change my luck if I changed my name. Did it bring me any luck, I wonder- calling myself Sasha?

Was it in 1926 or 1927?" (Rhys, 1939, p.12)

Here, place is a more significant point of reference for Sasha's memory than time. Her sense of identity is clearly associated with the place she happens to find herself in. Throughout the novel, Sasha recalls specific placed-based memories. She remembers "standing in the middle of the Place de l'Opera, losing [her] head and not knowing the way to the Rue de la Paix" (Rhys, 1939, p.30) from her time working as a tour guide, "blue sky over the streets, the houses, the bars, the cafes, the vegetable shops and the Faubourg Montmartre" (Rhys, 1939, p.128) before her husband leaves her, and that "there used to be a good hat shop in the Rue Vavin" (Rhys, 1939, p.68). There are places where she is liked, streets that are "friendly," rooms where she "might" be happy, looking glasses she looks nice in and dresses that will be lucky (Rhys, 1939, p.46). Sasha relies on the locales she is familiar with to orient herself in a city where she constantly feels the need to hide and to be anonymous.

It's particularly important to note that the places Sasha frequents comprise a highly commercialised and commodified world of Paris and while Sasha is taking her flanerie she makes frequent references to mannequins, window shopping, 
clothing and make-up as a critique of the alienating effects of fashion, consumption and commodification upon female identity.

Like other Rhys heroines, Sasha's lack of a secure background makes consumption (as a way to attain a measure of identity) intrinsic to her experience of modernity. To be able to fit in the society in which she's marginalized (for her sex, her class, her problematic national identity), Sasha is engaged in a complete transformation of self. She changes her name from Sophia to Sasha in the hope "it might change my luck"; she dyes her hair "a very good blond cendre"; and she changes her costumes: "I must go and buy a hat this afternoon, I think, and tomorrow a dress." (Rhys, 1939, p.11, p.53). She refers to her made-up face as a mask that can be manipulated at will: "I can take it off whenever I like and hang it up on a nail." (37) She defines the success of this transformation act as the ability to "look like everyone else"(88), that "Nobody stares at me"(60) and states ironically: "I am trying so hard to be like you" (88). Yet despite these attempts, Sasha concludes: "they always see through me" (28). In Modernism and the Marketplace, Alissa Karl argues that, in Rhys's texts, consumerism is inscribed with imperialist domination because it is the vehicle through which "national culture is accessible" (Karl, 2009, p.17). Yet while Sasha tries to obtain an identity through purchase of costumes and masks so that she may escape alienation, she also realizes acceptance can never be achieved because of this "imperial domination" and exclusion.

As women like Sasha are trying to buy themselves an illusion of identity that meets with society's values, they are also aware of the objectifying male-gaze which they can not help internalize. The patriarchal paradigm, together with mechanics of consumerism finds the female body and its image highly commodifiable: women become a commodity spectacle and are turned victims of such objectification and commodification. While they consume the products of fashion industry and assume the mass produced fashionable identities, they become interchangeable with mannequins displayed in department store windows, as Sasha ironically comments on the "charming, malicious" dolls in the fashion house: "What a success they would have made of their lives if they had been women. Satin skin, silk hair, velvet eyes, sawdust heart-all complete" (Rhys, 1939, p.16).

The commodification of women, with fashion, advertising and entertainment as its accomplices, is more striking in the case of the prostitute, which Benjamin gives extended discussion in One Way Street and Arcades Project. Rita Felski in The Gender of Modernity discusses "The prostitute, the actress, the mechanical woman" in particular as "heroines of modernity" and declares that "it is such female figures that crystallize the ambivalent responses to capitalism and technology which permeated nineteenth-century culture" (Felski, 1995, p.20). It's not surprising to find that Rhys's heroines fit into all three categories, both Marya in Quartet and Julia in ALMM have worked as model and mannequin, Anna in VD is a chorus girl and mistress, Sasha in GMM worked as a salesgirl, all of them are connected to the role of prostitute one way or another, and more significantly, they often perform more than one of these roles simultaneously.

Luce Irigaray in Women on the Market analyzes the circulation and consumption of women by men in the institutions of prostitution and marriage. She argues that women enter the symbolic order as objects circulated and exchanged by men, and in this system of exchange, a woman is "transformed into a value-bearing object, a standardized sign, an exchangeable signifier"(Irigaray, 1985, p.180). As commodities, women have either a use value or an exchange value. In either case, women are subjected to economic exploitation, sexual prejudice or racism. The forms of prostitution may have evolved but they never disappear. As Benjamin observes, the commodification of female sexuality in modernity has changed with the changing conditions of capitalist production: the chorus girls are produced like on the assembly line. Hence what modernity brings as a difference is not the nature of such exploitation, but the scale and diversity of it. Sasha, when being sacked by the English manager, gives a fierce indictment of the "organized society" in the terms of exchange value and how the exploited is robbed of both money and dignity:

"You, who represent Society, have the right to pay me four hundred francs a month. That' s my market value, for I am an inefficient member of society, slow in the uptake, uncertain, slightly damaged in the fray, there' s no denying it."(Rhys, 1939, p.25)

"Let's say you have the mystical right to cut my legs off. But the right to ridicule me because I am a cripple-no, that I think you haven't got. And that's the right you hold must dearly, isn't it? You must be able to despise the people you exploit" (29).

Here Sasha presents the Rhys women's dilemma, that because of their poverty they must circulate, but because of their circulation, they become damaged goods, their value depreciates accordingly. They have to continue to invest in their clothes and appearance in order to sustain their status as increasingly devalued commodities.

"The machine-woman" is also discussed as a recurring theme in modern times. Andreas Huyssen notes in "The Vamp and the Machine" that this image comes to crystallize in condensed form a simultaneous fascination and revulsion with the powers of technology. Yet this figure of the woman as machine can also be read as the reaffirmation of a patriarchal desire for technological mastery over woman, expressed in the fantasy of a compliant female automaton (Felski, 1995, p.20). Sasha, who feels powerless against the manipulation of the mechanics of consumerism and exchange, is profoundly aware of its dehumanizing and automatizing effect. She describes her anonymous, mechanical existence in endless repetition:

"Eat. Drink. Walk. March. Back to the hotel. To the Hotel of Arrival, the Hotel of Departure, the Hotel of the Future, the Hotel of Martinique and the Universe. ... Back to the hotel without a name in the street without a name. You press 
the button and the door opens. This is the Hotel Without-a-Name in the Street Without-a-Name, and the clients have no names, no faces. You go up the stairs. Always the same stairs, always the same room."(Rhys, 1939, p.120)

With the Paris 1937 Exposition Internationale des Arts et Techniques Applique a la Vie Moderne as an important backdrop that converge modern technology, the rise of fascism and competition of imperial power, Sasha reacts that she"feel like an automaton", she has forgotten "what it was like, the touch of a human hand"(Rhys, 1939, p.84) , indicating her own mechanization into an automaton, and she sees artificial limbs in a shop-window and mechanical hand in her nightmare that points her to the Exhibition. In the end of the novel, she feels the entire world is "an enormous machine, made of white steel." While the Exhibition foregrounds the modern, progressive ideology of nation and nationalism, demonstrates material wealth and progress in the machine age, it also focuses on imperial display and global reach of imperial-capital, betrays racism and European imperial expansion.

\section{CONCLUSION}

In the introduction Ford Madox Ford wrote for Rhys's first published work, The Left Bank and Other Stories, he states that "Her business was with passion, hardship, emotions: the locality in which these things are endured is immaterial," and then concedes that "something human should be dearer to one than all the topographies of the world" (Ford, 1927, p. 24-26). Yet place, locality and the space produced in between are by no means immaterial in her work. The vagueness in location and boundaries in Rhys's fiction, both in terms of geography and identity, are more revealing of the particular existence her characters find themselves in. The outcasts, the impoverished diasporas and the Creoles all experience a displacement and such displacement are results of a history of European imperialism and colonial exploitation. In imperial England, when failing to comply with a rigid social code of Englishness, gentility and purity, they are rejected, unhoused, wandering in a state of limbo, and their existence becomes mechanical, ghostly, hostage to the coercive and dehumanizing imperialist ideology. In Paris, they experience a disorientation and identity loss resulted from the capitalist consumerism and capitalist imperialism the capital of modernity embodies. It is this sense of having no identity and no place of belonging resulted from a very specific and traumatic colonial experience that best explains the pervasive tone of loss, melancholy, and paralysis of spirit underlying all of Rhys's fiction.

\section{REFERENCES}

[1] Felski, Rita. (1995). The Gender of Modernity. Cambridge, Mass.: Harvard University Press.

[2] Ford Madox Ford. (1927). Introduction to The Left Bank and Other Stories by Jean Rhys. London: Jonathan Cape, 7-27.

[3] Gikandi, Simon. (1996). Maps of Englishness: Writing Identity in the Culture of Colonialism. New York: Columbia UP.

[4] Irigaray, Luce. (1985). The Sex Which is Not One. New York: Cornell University Press.

[5] Karl, Alissa G. (2009). Modernism and the Marketplace: Literary Culture and Consumer Capitalism in Rhys, Woolf, Stein, and Nella Larsen. New York: Routledge.

[6] Massey, D. (1994). Space, Place and Gender. Cambridge: Polity Press.

[7] McClintock, Anna. (1995). Imperial Leather: Race, Gender and Sexuality in the Colonial Contest. New York and London: Routledge.

[8] Parsons, Deborah L. (2000). Streetwalking the Metropolis: Women, the City, and Modernity. Oxford: Oxford UP.

[9] Rhys, Jean. (1927) 1984. The Left Bank and Other Stories. London: Cape. Reprint, Salem: Ayer.

[10] Rhys, Jean.. (1929) 1997.Quartet. New York: Simon and Shuster. Reprint, New York: Norton.

[11] Rhys, Jean. (1934) 1994. Voyage in the Dark. London: Constable. Reprint, New York: Norton.

[12] Rhys, Jean. (1939) 1999. Good Morning, Midnight. London: Constable. Reprint, New York: Norton.

[13] Rhys, Jean. (1979). Smile Please: An Unfinished Autobiography. Berkeley: Donald S. Ellis/Creative Arts.

[14] Savory, Elaine. (2009). The Cambridge Introduction to Jean Rhys. Cambridge: Cambridge UP.

[15] Thacker, Andrew. (2003). Moving through Modernity: Space and Geography in Modernism. Manchester: Manchester UP.

[16] Turner, Victor W. (1969). The Ritual Process. Structure and Anti-Structure. Chicago: Aidine Publishing.

Lin Yan is a Ph.D candidate majoring in English language and literature from the School of English, Shanghai International Studies University. She has been a teaching assistant in Department of English, Zhejiang University City College for four years. Her published essays include a translated article "Ezra Pound, Confucius, and the Fenollosa Notebooks: 'The Very Real Principle of Modernism' by Anne Conover Carson (English and American Literary Studies, spring 2011), and a book chapter "Thackeray in China" in Studies of British Literature in $20^{\text {th }}$ Century China (Shanghai Foreign Language Education Press, 2014). Her research interests mainly focus on modernist and contemporary British literature. 